\title{
EFFECTIVENESS OF LYSIPHLEBUS TESTACË̈PES CRESSON AS BIOCONTROL AGENT OF APHIS GOSSYPII GLOVER INFESTING PEPPER PLANTS
}

\author{
M. BEN HALIMA KAMEL \\ Institut Supérieur Agronomique de Chott Mariem 4042, Sousse University Tunisia \\ UR 04AGRO4: Invertébrés, microorganismes, malherbes nuisibles: Méthodes alternatives de lutte. \\ Tel 0021673327544, Fax 0021673327591 \\ *Corresponding author: kamonia_tn@yahoo.fr
}

\section{ABSTRACT}

In Tunisia, greenhouse crops are damaged by Aphis gossypii Glover and Myzus persicae Sulzer (Ben Halima Kamel 1991; Ben Halima Kamel and Ben Hamouda 1993, 1998). These aphids are considered to be the most dangerous pests of pepper because of their biology and biotic potential (Ben Halima Kamel 1991; Blackman and Eastop 2000). There are several ways of controlling these pests with chemical control being the most widely used. This method has more disadvantages than benefits (Gibson et al. 1982). The use of natural enemies to control aphids is an effective way of improving the yield and quality of protected crops. There are many studies on the following naturally occurring enemies of A. gossypii: Aphidius matricariae Haliday, Lysiphlebus fabarum Marshall, Aphidoletes aphidimyza (Rondani), Episyrphus balteatus (De Geer) (Ben Halima Kamel and Ben Hamouda 1998) and Lysiphlebus testaceipes (Cresson) (Ben Halima Kamel, unpublished data, 1999). It is now important to evaluate the effectiveness of $L$. testaceipes as a biocontrol agent of $A$. gossypii. This parasitoïd was introduced into the Mediterranean area (Carver and Franzmann 2001) and is thought to be an important parasite of A. gossypii (Lopes et al. 2007). The aim of this mainly laboratory study was to determine the factors affecting the establishment and success of a biological control agent, in particular the number of $L$. testaceipes relative to the initial density of $A$. gossypii, needed to control the aphid. In addition, the effect of the $L$. testaceipes on structure of $A$. gossypii populations was evaluated. Furthermore, the effectiveness of $L$. testaceipes in controlling A. gossypii infesting a protected crop of pepper plants and the subsequent effect on the growth of the pepper plants was also evaluated.

Keywords: Lysiphlebus testaceïpes, pepper, Aphis gossypii, biocontrol, protected crop

\section{Introduction}

The pests Bemisia tabaci Gennadius, Spodoptera littoralis Boiduval, Tetranychus urticae Koch (Jerraya 2003), Aphis gossypii Glover and Myzus persicae Sulzer infest and damage protected crops (Ben Halima Kamel 1991; Ben Halima Kamel and Ben Hamouda 1993). Protected crops, particularly pepper, can be heavily infested by aphids, which seriously affect the yield and quality of the crop (Ben Halima Kamel 1991; Ben Halima Kamel and Ben Hamouda 1993; Blackman and Eastop 2000). In Tunisia, these aphids are controlled by spraying pesticides and plant extracts (Ben Halima Kamel et al. 2001) and by the release of Coccinella algerica Kovar (Ben Halima Kamel $2005,2010)$. However, this method's are not very effective in controlling this pest.

Worldwide, the control of aphid pests depends mainly on the frequent application of synthetic insecticides, which often results in both the aphids and their natural enemies by developing resistance to these products (Sun et al. 1994). Chemical control is not an ideal method because it has many negative effects, such as the development of resistance (Gibson et al. 1982) and associated environmental problems, such as pollution of water, presence of toxic residues in food and the effects of pesticides on human health (Laher et al. 2000; Akol et al. 2002; Pavela et al. 2004).

Biocontrol is an alternative method, which is not only ecologically, but also economically and socially sound.
For the successful biological control of aphids, it is necessary to search for effective natural enemies, particularly those that can be used to control aphids on crops (Rabasse and Van Steenis 1987). In this context the following aphid natural enemies was occurred in Tunisia: Aphidius matricariae Haliday, Lysiphlebus fabarum Marshall, Aphidoletes aphidimyza Rondani, Episyrphus balteatus De Geer (Ben Halima Kamel and Ben Hamouda 1998) and Lysiphlebus testaceïpes Cresson was recorded in 1999 (Ben Halima Kamel unpublished data). This parasitoid was introduced into the Mediterranean area (Costa and Stary 1988). The importance and effectiveness of $L$. testaceïpes in controlling A. gossypii was determined (Rochat 1997; Lopes et al. 2007).

The success of biological control programs depend on the natural enemy used, the crop and the area to be treated. Nevertheless, little information is known about the numbers of natural enemies that need to be released for biological control, especially parasitoids. In Tunisia, the most effective rate of release varies depending on the crop infested by the target pest and the biocontrol agent. There is a need to determine the appropriate release rate based on the biology of the pest and the natural enemy(s) to be used to control the pest.

In this study, the precise needed number of $L$. testaceipes to be released to control populations of A. gossypii of different initial densities in the laboratory was determined. Moreover the efficiency of this parasitoid in con- 
trolling A. gossypii infesting a greenhouse of peppers was determined and the subsequent effect on the growth of the plants was assessed.

\section{Material and methods}

\section{Bioassays carried out under laboratory conditions}

The pepper Capsicum annuum L. variety Alter was used as the host plant in all the experiments. The plants were isolated in cylindrical boxes covered with muslin and kept in controlled conditions. At the 8th leaf stage, plants were infested with A. gossypii and covered until required.

A. gossypii was reared on pepper under controlled laboratory conditions of $20 \pm 2{ }^{\circ} \mathrm{C}$ and a photoperiod $16 / 8(\mathrm{~L} / \mathrm{D})$. These aphids were used to infest the pepper plants used in the experiments detailed below. A laboratory stock of the parasitoid L. testaceippes was maintained using the aphid Rhopalosiphum padi (L.) infesting barley as the host.

The numbers of A. gossypii infesting each plant in each cage ranged from D1 to D4, and the numbers of parasitoids from zero to 8 (Table 1). The controls consisted of cages with infested plants but without $L$. testaceïpes (Table 1). Four plants were used in each treatment.
The numbers of aphids on the plants was counted 7 days after the introduction of $L$. testaceïpes into the cages. The numbers of the different stages: young larvae, old larvae, nymphs, apterae, winged aphids, mummified aphids, mummies from which parasitoids had emerged, were counted.

Table 1 The numbers of aphids and parasitoids used in each treatment.

\begin{tabular}{|l|l|l|l|l|l|}
\hline Number of aphids & \multicolumn{5}{|c|}{ Number of $L$. testaceïpes } \\
\hline D1: $>10<40$ & 0 & 1 & 2 & 4 & 8 \\
\hline D2: $>40<80$ & 0 & 1 & 2 & 4 & 8 \\
\hline D3: $>80<150$ & 0 & 1 & 2 & 4 & 8 \\
\hline D4: $>150$ & 0 & 1 & 2 & 4 & 8 \\
\hline
\end{tabular}

\section{Experiments in a greenhouse containing a pepper crop}

The greenhouse covered $384 \mathrm{~m}^{2}(32 \mathrm{~m}$ long $\times 12 \mathrm{~m}$ wide), was planted on 7/10/2007 and located at the Technical Center of Organic Farming in Chott Mariem. This is in the coastal area of Tunisia, which has an arid climate. The temperature and the relative humidity in the greenhouse were recorded using a thermohygrograph.

We released 250, 50 and $64 L$. testaceïpes, respectively, in the greenhouse on $18 / 12 / 07,24 / 12 / 07$ and $2 / 1 / 08$. The

Table 2 Effectiveness after seven days, of different numbers of $L$. testaceïpes in reducing the abundance of $A$. gossypii infesting pepper plants in laboratory conditions.

\begin{tabular}{|c|c|c|c|c|c|c|c|c|c|}
\hline 7 days & Density & $\begin{array}{c}\text { Global } \\
\text { population }{ }^{1}\end{array}$ & Young larvae $^{1}$ & Old larvae ${ }^{1}$ & Nymphal ${ }^{1}$ & Aptera ${ }^{1}$ & Winged 1 & Mummies $^{1}$ & $\begin{array}{l}\text { Hatched } \\
\text { mummies }^{1}\end{array}$ \\
\hline \multirow{4}{*}{ Control } & D1 & $62.25 \pm 3.4 \mathrm{def}$ & $28.75 \pm 6.7 \mathrm{def}$ & $13.5 \pm 3.1 b c$ & $7.75 \pm 4.5 \mathrm{ab}$ & $8.75 \pm 2.9 a b$ & $3.5 \pm 2.0 \mathrm{a}$ & $0.00 \pm 0.0 a$ & $0.00 \pm 0.0 a$ \\
\hline & D2 & $157.75 \pm 15.2 \mathrm{gh}$ & $41.00 \pm 14.9 f$ & $47.25 \pm 4.6 f$ & $25.5 \pm 7.9 \mathrm{de}$ & $19.25 \pm 10.5 \mathrm{de}$ & $12.25 \pm 2.9 a b$ & $0.00 \pm 0.0 a$ & $0.00 \pm 0.0 a$ \\
\hline & D3 & $229.25 \pm 13.2 i$ & $59.75 \pm 17.4 \mathrm{~g}$ & $51.00 \pm 11.3 f$ & $39.5 \pm 12.8 \mathrm{e}$ & $39.00 \pm 10.4 \mathrm{e}$ & $40 \pm 11.1 d$ & $0.00 \pm 0.0 a$ & $0.00 \pm 0.0 a$ \\
\hline & D4 & $577.25 \pm 27.11$ & $130.00 \pm 17.3 i$ & $111.25 \pm \mathrm{i}$ & $97.75 \pm 11.1 \mathrm{~g}$ & $103.25 \pm 17.4 \mathrm{~g}$ & $135 \pm 14.0 \mathrm{~g}$ & $0.00 \pm 0.0 a$ & $0.00 \pm 0.0 a$ \\
\hline \multirow{4}{*}{$\begin{array}{c}1 \\
\text { parasitoid }\end{array}$} & D1 & $42.25 \pm 3.4 \mathrm{~cd}$ & $16.5 \pm 3.8 \mathrm{abcd}$ & $8.75 \pm 2.5 \mathrm{ab}$ & $4.25 \pm 1.7 a$ & $10.5 \pm 1.3 a b$ & $1.5 \pm 1.0 \mathrm{a}$ & $0.75 \pm 0.5 \mathrm{ab}$ & $0.00 \pm 0.0 a$ \\
\hline & $\mathrm{D} 2$ & $51.75 \pm 2.0 \mathrm{cde}$ & $18.75 \pm 0.9 b c d e$ & $12.5 \pm 2.6 b c$ & $9.25 \pm 0.9 \mathrm{ab}$ & $9.75 \pm 1.7 a b$ & $0.25 \pm 0.05 a$ & $1.25 \pm 0.5 b$ & $0.5 \pm 0.05 a b c$ \\
\hline & D3 & $131.25 \pm 10.1 \mathrm{~g}$ & $40.75 \pm 9.7 f$ & $26.5 \pm 6.2 \mathrm{de}$ & $19.75 \pm 1.7 \mathrm{bcd}$ & $21 \pm 2.1 \mathrm{bcd}$ & $22.25 \pm 2.9 b c$ & $1.00 \pm 0.8 \mathrm{ab}$ & $0.25 \pm 0.05 a b$ \\
\hline & D4 & $485.5 \pm 17.4 k$ & $104.00 \pm 8.2 \mathrm{~h}$ & $105.25 \pm 2.8 i$ & $66.5 \pm 2.2 f$ & $95.25 \pm 8.3 \mathrm{fg}$ & $113.5 \pm 6.2 f$ & $1.00 \pm 0.9 a b$ & $0.00 \pm 0.0 a$ \\
\hline \multirow{4}{*}{$\begin{array}{c}2 \\
\text { parasitoid }\end{array}$} & D1 & $31.75 \pm 8.8 \mathrm{abcd}$ & $15.00 \pm 6.3 \mathrm{abcd}$ & $4.5 \pm 1.9 a b$ & $5.00 \pm 1.4 a$ & $3.00 \pm 1.4 a$ & $2.5 \pm 1.3 a$ & $1.75 \pm 0.5 b$ & $0.25 \pm 0.05 a b$ \\
\hline & D2 & $38.25 \pm 5.9 b c d$ & $13.5 \pm 4.8 \mathrm{abcd}$ & $6.00 \pm 1.4 a b$ & $8.00 \pm 2.4 a b$ & $6.00 \pm 1.4 a b$ & $3.25 \pm 0.9 a$ & $1.5 \pm 1.2 b$ & $0.25 \pm 0.5 \mathrm{ab}$ \\
\hline & D3 & $91.00 \pm 12.9 f$ & $35.00 \pm 4.1$ ef & $14.5 \pm 5.0 b c$ & $9.75 \pm 3.3 a b$ & $14.5 \pm 5.0 \mathrm{abcd}$ & $11.75 \pm 3.0 \mathrm{ab}$ & $5.00 \pm 0.8 e$ & $1.25 \pm 0.9 c d$ \\
\hline & D4 & $470.75 \pm 11.0 k$ & $105.00 \pm 17.8 \mathrm{~h}$ & $94.75 \pm 13.8 h$ & $77.75 \pm 9.1 f$ & $84.25 \pm 16.2 f$ & $105.25 \pm 6.5 f$ & $3.25 \pm 0.8 \mathrm{~cd}$ & $1.25 \pm 0.9 \mathrm{~cd}$ \\
\hline \multirow{4}{*}{$\begin{array}{c}4 \\
\text { parasitoid }\end{array}$} & D1 & $25.75 \pm 11.5 a b c$ & $11.75 \pm 4.3 \mathrm{abcd}$ & $7.00 \pm 3.4 a b$ & $1.75 \pm 1.7 a$ & $1.75 \pm 2.3 a$ & $0.5 \pm 0.1 \mathrm{a}$ & $3.00 \pm 0.8 c$ & $1.00 \pm 0.8 b c$ \\
\hline & D2 & $26.75 \pm 3.8 a b c$ & $7.25 \pm 2.7 a b c$ & $4.75 \pm 1.7 a b$ & $3.00 \pm 0.8 a$ & $7.00 \pm 2.5 \mathrm{ab}$ & $0.5 \pm 0.1 \mathrm{a}$ & $4.25 \pm 1.8 \mathrm{de}$ & $2.00 \pm 0.8 \mathrm{de}$ \\
\hline & D3 & $82 \pm 6.3 e f$ & $20.25 \pm 4.5 \mathrm{cde}$ & $22.00 \pm 2.2 \mathrm{~cd}$ & $13.25 \pm 2.4 \mathrm{abc}$ & $12.5 \pm 1.9 a b c$ & $9.75 \pm 1.7 a b$ & $4.25 \pm 1.2 \mathrm{de}$ & $1.00 \pm 0.8 b c$ \\
\hline & D4 & $442.75 \pm 81.2 j$ & $98.25 \pm 27.0 \mathrm{~h}$ & $84.75 \pm 12.6 \mathrm{~g}$ & $76.25 \pm 113.9 f$ & $85.75 \pm 16.4 f$ & $92.5 \pm 19.8 \mathrm{e}$ & $5.25 \pm 0.9 e$ & $0.75 \pm 0.09 a b c$ \\
\hline \multirow{4}{*}{$\begin{array}{c}8 \\
\text { parasitoid }\end{array}$} & D1 & $6.75 \pm 0.9 a$ & $0.00 \pm 0.0 a$ & $0.00 \pm 0.0 a$ & $0.00 \pm 0.0 a$ & $0.00 \pm 0.0 a$ & $0.00 \pm 0.0 a$ & $6.75 \pm 0.9 f g$ & $5.75 \pm 0.9 g$ \\
\hline & D2 & $8.00 \pm 1.1 \mathrm{ab}$ & $0.5 \pm 0.1 \mathrm{ab}$ & $0.5 \pm 0.1 \mathrm{a}$ & $0.25 \pm 0.05 a$ & $0.5 \pm 0.05 a$ & $0.00 \pm 0.0 \mathrm{a}$ & $6.25 \pm 0.9 f$ & $4.00 \pm 1.1 f$ \\
\hline & D3 & $83.5 \pm 7.6 f$ & $16.25 \pm 4.0 \mathrm{abcd}$ & $19.5 \pm c 2.1 d$ & $12.25 \pm 2.2 \mathrm{abc}$ & $15.5 \pm 6.24 \mathrm{abcd}$ & $12.25 \pm 2.7 \mathrm{ab}$ & $7.75 \pm 0.9 \mathrm{~g}$ & $2.25 \pm 0.9 \mathrm{e}$ \\
\hline & D4 & $169.5 \pm 9.6 h$ & $46.25 \pm 4.0 \mathrm{fg}$ & $34.25 \pm 6.6 e$ & $24.00 \pm 18.5 \mathrm{~cd}$ & $25.5 \pm 2.4 \mathrm{cde}$ & $31.75 \pm 6.3 \mathrm{~cd}$ & $7.75 \pm 0.9 g$ & $2.00 \pm 0.8 \mathrm{de}$ \\
\hline
\end{tabular}

1 Mean values with the same superscript letter are not significantly different $(P<0.05)$.

D1 $=$ Density of aphids between 10 and 40 per plant, $\mathbf{D} \mathbf{2}=$ Density of aphids between 40 and 80 per plant, $\mathbf{D} \mathbf{3}=$ Density of aphids between 80 and 150 per plant, $\mathbf{D 4}=$ Density of aphids more than 150 per plant 
30 untreated plants were isolated in cylindrical boxes covered with muslin. At the same time, 30 treated plants were taken. The number of aphids per plant and the height of the pepper plants were recorded weekly.

\section{Statistical analysis}

For the laboratory assays, the experimental results were statistically analyzed using the SPSS 13 program and a one-way analysis of variance and a Duncan test, with statistical significance set at $a=0.05$. The numbers of aphids on treated and control plants in the pepper crop at different times were also compared.

\section{Results}

\section{Effect of different numbers of $L$. testaceïpes in controlling different sized populations of A. gossypii}

Statistical analyses of the numbers of, each stage and morph of the aphid in the different treatments seven days after the release of $L$. testaceipes revealed that the parasitoid had a significant effect on the abundance of the aphids. The release of two parasitoids per plant resulted in a significant decrease in the number of aphids in each stage of development, especially in the D1 and D2 treatments (Table 2).

A detailed study demonstrated the effect of $L$. testaceippes on the number of young larvae produced per adult aphid, which is 28.75 in the control and 15.00 when two parasitoids were released per plant. This can be attributed to the effect that parasitoid oviposition has on the aphids. The effect of releasing one parasitoid in the low density treatment (D1) was to reduce the production from 13.5 in the control to 8.75. Similar results were obtained for nymphs, apterae and winged aphids, all of which were less abundant even in those treatments in which only one parasitoid was released. Thus, infestations of less than 80 aphids per plant can be controlled by releasing two parasitoids per plant, but to control infestations of more than 80 aphids per plant the use of eight parasitoids per plant is necessary. The maximum number of mummies was recorded when eight parasitoids per plant were released, which indicates that this is the optimum treatment if the objective is to maximize the production of parasitoids.

\section{Effectiveness of L. testaceippes as a biocontrol agent of A. gossypii infesting protected pepper crops}

The release of 250, 50 and 64 individuals of $L$. testaceïpes, respectively, on 18/12/07, 24/12/07 and 2/1/08 resulted in a gradual decrease in the abundance of $A$. gossypii. The population on the control plants reached more than 1000 aphids per plant compared to less than 40 aphids per plant on the treated plants (Fig. 1) after the first release. The results indicate that the aphid population density decreased from 40 to 10 aphids per plant after the first introduction of L. testaceippes (Fig. 1). The decrease

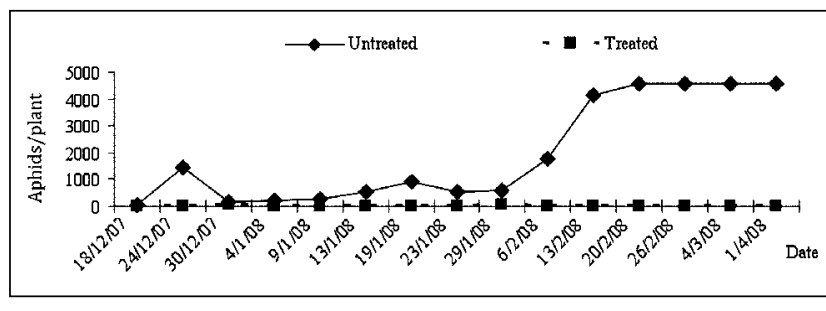

Fig. 1 Trends in the numbers of aphids infesting both pepper plants that were exposed to parasitoids (treated) and in the control cages.

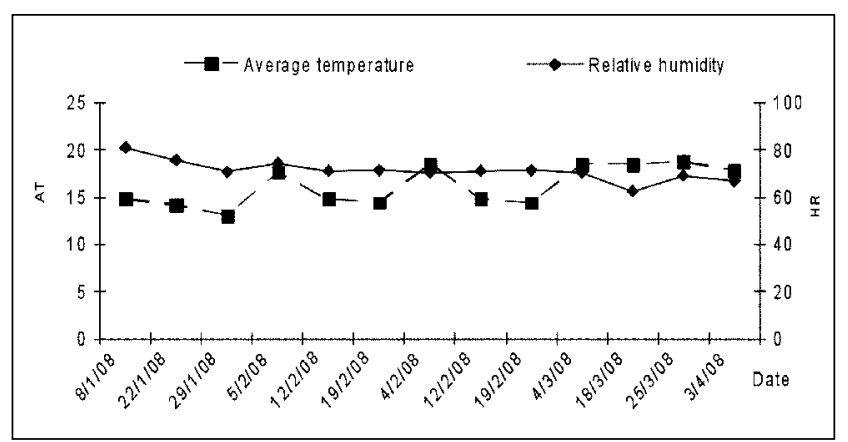

Fig. 2 Trends in the averages temperatures (AT) and relative humidity (HR) recorded in the pepper crop throughout the study.

in aphid abundance that occurred on the control plants between 30/12/07 and 29/1/08 was possibly due to the low temperatures prevailing during this period (Fig. 2).

From February until April, the population of aphids on the control plants began to rise again; there were 4582 aphids per plant on $1 / 4 / 08$. At that time there were only 10 aphids per plant on the plants on which Lysiphlebus were released earlier in the year. Moreover this result indicates that releasing approximately 1 parasitoid per $\mathrm{m}^{2}$ results in a decrease in the abundance of A. gossypii.

\section{Effect of releasing L. testaceïpes to control aphids on the growth of pepper plants}

The control pepper plants were more heavily infested with aphids and smaller than the plants on which the parasitoids were released (Fig. 3). In the first week of January the treated plants were $70 \mathrm{~cm}$ high whereas the control plants were only $35 \mathrm{~cm}$ high. This difference was maintained until the end of experiment.

\section{Discussion}

The results indicate that the population of aphids decreased significantly after the release of $L$. testaceipes. This study focused on the reductions in the abundance of A. gossypii following augmentative releases of L. testaceïpes. Similarly, the augmentative introduction of coccinellids decreases the population densities of target pests (Abd-Rabou 2008). Lysiphlebus proved effective when one and two parasitoids were released if the aphid population densities were low (D1 and D2). In contrast, when the aphid population densities are high (D3 and D4) a release 


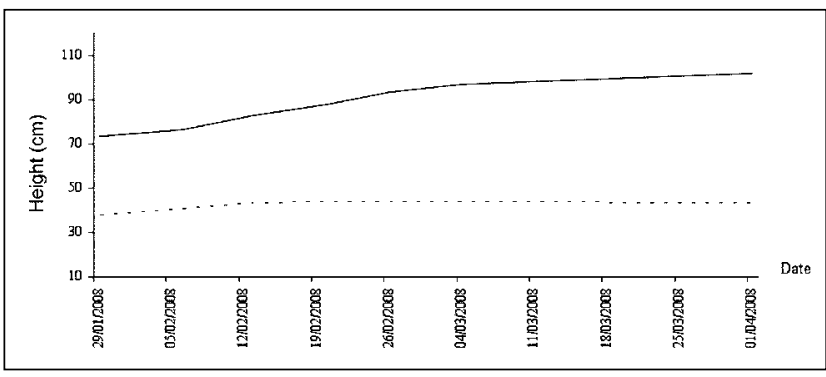

Fig. 3 Height of the pepper plants exposed to parasitoids (treated) compared to that of the control plants.

of eight parasitoids is required to control this pest. This was reflected in the decrease in the number of mummies and winged aphids relative to the control (Table 2). At high aphid population densities, winged aphids develop, which disperse to other plants (Dixon 1973; 1985 in Lopez et al. 2007). Recently Lombaert et al. (2006) reported that A. gossypii infesting cultivated melon plants also has a density dependant dispersal strategy.

There is little information on the functional response of $L$. testaceïpes in the host-parasitoid system studied. Van Steenis (1994) showed that $L$. testaceïpes isn't very efficient at finding aphids when they are uncommon, which suggests that this parasitoid has a type 3 functional response. The parameters of the functional response of L. testaceïpes have been estimated in the laboratory using different densities of A. gossypii (from 2 to 128 aphids) feeding on cucumber leaf disks in boxes (Rochat 1997). On average, $L$. testaceïpes exhibits a type 2 functional response to A. gossypii at low densities. This is similar to the observations recorded by Van Steenis (1994) (cited in Rochat 1997). However, young naïve females have a type 3 functional response (Rochat 1997).

The results obtained, when different densities of aphids and releases of parasitoids are used, suggest that learning to respond to uninfested plants may prolong the period for which parasitoids forage in a habitat during periods when there few aphids and host-induced volatiles are scarce or absent (Powell et al. 1998 in Lo Pinto et al. 2004). It is also suggested that plants may produce, even if in low quantities, the same odours as those produced by host insects. This has been demonstrated, for example, for the alarm pheromone of S. graminum, which is detectable in the volatile profile of undamaged wheat plants (Grasswitz and Paine 1993 in Lo Pinto et al. 2004).

It is assumed that the pest populations will increase exponentially unless controlled in some way (Fig. 1). There is no time delay in the increase in the aphid population because the generations completely overlap (Dixon 1987). The release of Lysiphlebus in the greenhouse containing pepper plants infested with A. gossypii resulted in a reduction in the level of the infestation relative to the infestation of the control plants. This was obtained by releasing the parasitoid early when the infestation was 40 aphids per plant. The level of aphid control obtained by releasing $L$. testaceippes in the greenhouse was reflected in an improved growth of the pepper plants over that of the control plants (Fig. 3). There is no doubt that aphids have a pronounced adverse affect on the growth of plants. In natural habitats aphids also reduce the fitness of their host plant. It's known that aphids affect the yield and quality of the seed of several crop plants. For example Aphis fabae Scopoli reduces the numbers of seeds produced by bean plants by up to $86 \%$ and the average weight of a bean by 45\% (Banks and Macaulay 1967 in Dixon 1998). Similarly, aphids reduce the yield of cereals. In addition, high numbers of the spruce aphid Elatobium abietinum can cause the defoliation of spruce, which if recurrent can cause the death of trees (Dixon 1998).

\section{Conclusions}

The present results confirm that the release of $L$. testaceïpes is an effective way of controlling aphids infesting pepper plants in greenhouses in Tunisia. This control will be further optimised by defining when the parasitoids should be released, how frequently and at what aphid population density. Nevertheless other studies are needed on the mass production, manipulation, release and evaluation of the effectiveness of $L$. testaceipes in reducing the abundance of A. gossypii infesting crops at different locations in Tunisia.

Moreover, information on the presence and biology of L. testaceipes in other areas of Tunisia is needed for a better understanding of its distribution and ecology, and importance as a biocontrol agent. In addition, such data on an immigrant/introduced species will increase the understanding of the ability exotic species to adapt to a new area of the Mediterranean (Kavallieratos et al. 2004).

\section{Acknowledgments}

We are most grateful to Pr. Ben Kheder Mohamed for financial support. We also extend special thanks to Braham Badra for technical assistance in maintaining the stock culture of aphids and in the greenhouse.

\section{REFERENCES}

Abd-Rabou S (2008) Mass production, releasing and evaluation of the lady beetle, Coccinella undecimpunctata (Coleoptera: Coccinellidae), for control of aphids in Egypt. Arch Phytop and Plant Protection 41: 187-197.

Akol AM, Sithanantham S, Njagi PGN, Varela A, Mueke JM (2002) Relative safety of sprays of two neem insecticides to Diadegma mollipla (Holmgren), a parasitoid of the diamondback moth: effects on adult longevity and foraying behavior. Crop Protection 2: 853-859.

Ben Halima Kamel M (1991) Contribution à l'étude de la dynamique des populations aphidiennes en culture protégée. $\mathrm{PhD}$ thesis, Sciences University, Tunis. 
Ben Halima Kamel M (2005) Biological control of Aphis gossypii on pepper plant using Coccinella algerica. Com. Appl Biol Sci Ghent University 70: 737-743.

Ben Halima Kamel M (2010) Utilisation des différents stades biologiques de Coccinella algerica dans la lutte contre Aphis gossypii en serre de piment. In: Himmi O (eds) Actes de la CIFE VI: Travaux de l'Institut Scientifique, Série Zoologie 47, Rabat, Maroc, pp 109-112.

Ben Halima Kamel M, Ben Hamouda MH (1993) Les pucerons des cultures protégées et leurs ennemis en Tunisie. Tropicultura 11: 50-53.

Ben Halima Kamel M, Ben Hamouda MH (1998) Contribution à l'étude de la bioécologie des aphides d'une région côtière de la Tunisie. Med Fac Landb Univ Gent 63: 365-378.

Ben Halima Kamel M, Chaieb I, Ben Hamouda MH (2001) Sur l'utilisation des extraits des plantes biopesticides dans le contrôle des populations de puceron en culture protégée de piment. In: Iresa (ed) Acquis Récent de la Recherche Agronomique et Vétérinaire. Nabeul, Tunisie, pp 162-165.

Blackman RL, Eastop VF (2000) Aphids on the world's crops. An identification and information guide. The natural history museum. John Wiley and Sons, LTD, London, England.

Carver M, Franzmann B (2001) Lysiphlebus Förster (Hymenoptera: Braconidae: Aphididiinae) in Australia. Aust Ent 40: 198-201.

Costa A, Stary P (1998) Lysiphlebus testaceipes, an introduced aphid parasitoid in Portugal (Hym: Aphididae). BioControl 33: 403-402.

Dixon AFG (1973) Biology of aphids. Edward Arnold, London, UK.

Dixon AFG (1987) Parthenogenetic reproduction and the rate of increase in aphids. In: Minks and Harrewijn (eds) Aphids: vol 2A, Elsevier, pp 269-289.

Dixon AFG (1998) Aphid ecology. Second edition, Chapman \& Hall, London, UK.

Gibson RW, Rice AD, Pickett JA, Smith MC, Sawicki RM (1982) The effects of the repellents dodecanoic acid and polygodial on the acquisition of non-, semi- and persistent plant viruses by the aphid Myzus persicae. Ann Appl Biol 100: 55-59.
Jerraya A (2003) Principaux nuisibles des plantes cultivées et des denrées stockées en Afrique du Nord; leur biologie, leurs ennemis naturels, leurs dégâts et leurs contrôles. Climat Publication, Tunis.

Kavallieratos NG, Tomanovic Z, Stary P, Athanassiou CG, Sarlis GP, Petrovic O, Niketic M, Veroniki MA (2004) A survey of aphid parasitoids (Hymenoptera: Braconidae: Aphidiinae) of Southeastern Europe and their aphid-plant associations. Appl Ent Zool 39: 527-563.

Laher J, Gadji B, Dia D (2000) Predicted buffer zones to protect temporary pond invertebrates from ground-base insecticide applications against desert locust. Crop Protection 19: 489-500.

Lo Pinto M, Wajnberg E, Colazza S, Curty C, Fauvergue X (2004) Olfactory response of two aphid parasitoids, Lysiphlebus testaceipes and Aphidius colemani, to aphid-infested plants from a distance. The Netherlands Entomological Society, Ent Exp Appl 110: 159-164.

Lombaert E, Boll R, Lapchin L (2006) Dispersal strategies of phytophagous insects at a local scale: adaptive potential of aphids in an agricultural environment. BMC Evol Biol 6: 75.

Lopes C, Spataro T, Doursat C, Lapchin L, Arditi R (2007) An implicit approach to model plant infestation by insect pests. J Theor Biol 248: 164-178.

Pavela R, Barnet M, Kocourek F (2004) Effect of Azadirachtin applied systemically through roots of plants on the mortality, development and fecundity of the Cabbage aphid (Brevicoryne brassicae). Phytoparasitica 32: 286-294.

Rabasse JM, Van Steenis MJ (1987) Biological control of aphids. In: Albajes R et al. (eds) Integrated Pest and Disease Management in Greenhouse Crops. Kluwers Academics Publishers, Netherlands, pp 235-243.

Rochat J (1997) Delayed effect in aphid parasitoid Systems consequences for evaluating biological control species and their use in augmentative strategies. BioControl 42: 201-213.

Sun Y, Feng G, Yuan J, Gong K (1994) Insecticide resistance of cotton aphid in North China. Ent Sin 1: 242-250.

Van Steenis MJ (1994) Evaluation of four Aphidiine parasitoids for biological control of Aphis gossypii. Ent Exp Appl 75: 151-157. 